\title{
Innovation and graphic facilitation
}

\author{
Deborah Espiner ${ }^{1}$, and Frances Hartnett ${ }^{2}$
}

1 University of Auckland, New Zealand

${ }^{2}$ Independent contractor, Auckland, New Zealand

AOTEAROA

NEW ZEALAND SOCIAL WORK 28(4), 44-53.

CORRESPONDENCE TO: Deborah Espiner

d.espiner@auckland.ac.nz

\begin{abstract}
INTRODUCTION: Social work practice includes the facilitation of effective communication in planning, solution finding, developing shared understandings and collaborative decision making with individuals, families, colleagues and professionals and community groups. Changing social contexts require innovations and new approaches to practice.

METHODS: This article proposes that graphic facilitation (Sibbett, 1977, 2002) can be used as a way of enhancing social work practice by promoting anti-oppressive practice (Dominelli, 2002) and collaborative partnerships (Bracht, Kingsbury, \& Rissel, 1999; Roose, Roets, Van Houte, Vandenhole, \& Reynaert, 2013) and thinking differently (Gambrill, 2013).

Graphic facilitation is a practice that produces "rich pictures" (Checkland, 1981) to elicit and record information in a responsive and innovative way. Drawing on examples from practice, illustrations of the use of graphic facilitation will be presented in two contexts: person-centred planning and World Café.
\end{abstract}

FINDINGS: Literature supports the effectiveness of using graphics to develop a visual language and produce a "rich picture" that is easily understood and remembered. The use of pictures can stimulate new meaning and insight, and promote reflection and deep learning (Checkland, 1981; Horan, 2000). Graphic facilitation has been reported to increase engagement, understanding and result in a more energised process to bring about change.

CONCLUSIONS: Graphic facilitation is a method that can be added to a social work tool-box. The examples provided demonstrate the potential capacity of this approach to support individuals and groups in different, creative and innovative ways.

KEYWORDS: innovative practice, social work, creativity, graphic facilitation, rich pictures

Social workers face ever-changing social environments where "the nature and complexity of clients' problems and challenges ...continuously evolves and grows" (Nandan, London, Bent-Goodley, 2015, p. 1). Such changing contexts require innovations and new approaches to practice especially when engaging with individuals and groups who present with complex challenges. Innovation can be viewed as "a process for inventing something new or improving on that which already exists" (Blakeney, Carleton, McCarthy, \& Coakley, 2009, para. 1). Social workers have been encouraged to use the arts in practice to add to their repertoire, bring new insights and enrich communication (Känkänen \& Bardy, 2014). To sustain renewal and keep abreast in relation to capacity it becomes necessary to listen deeply to colleagues and clients, to look outside the immediate field of social work practice and to take positive risks. Brown (2010) considers taking risks in social work practice as a "central component of innovation" and, unless innovation is incorporated into "the delivery of front line services, future performance will remain inefficient and ineffective" (p. 1). Arts-based methods have offered creative approaches to work with vulnerable children 
(Coholic \& Eys, 2016) and in mental health (Armstrong \& Dorsett, 2015; Ho, Potash, Ho, Ho, \& Chen, 2016). This article illustrates the use of graphic facilitation as an innovative method, highlighting potential relevance and application in many social work contexts.

Some 30,000 to 25,000 years ago, humans were using symbols and colour and positioning these on a surface and within a space to record the tasks, triumphs and tribulations of daily life (Mendoza Straffon, 2014; Merkley, 2005). The power of these graphics when revisited thousands of years later is undeniable. The advent of writing and the written word largely supplanted the use of images, pictures, colour and form and became a major way of communicating. Visual language has more recently been promoted by technology, as visual images provide information in a language that people can understand (Checkland, 1981; Horn, 1998; Sibbett, 2002; Simpson, 2000). Furthermore, Anderson and Imperia (1992) purport that the visual image is louder than words capturing intention and feeling more clearly than words alone. If designed well, the visual image may result in increased appeal, comprehension and retention. Graphic facilitation has continued to be used in a range of situations including systems thinking (Checkland, 1981), strategic and personal planning (Sanderson, 2000). Graphic facilitation, as illustrated in Figure 1, is described as:

While people are presenting to the group or when a conversation or brainstorming session is taking place, a graphic recorder or graphic facilitator uses hand-drawn words and text, colours and pictures to summarise and organise the groups' thoughts and ideas (Mullen \& Thompson, 2013).

\section{Graphic facilitation}

Facilitation is "the art of leading people through processes toward agreed-upon objectives in a manner that encourages participation, ownership and creativity from all involved" (Sibbett, 2002, p. 1). The word facilitation comes from French (facile)

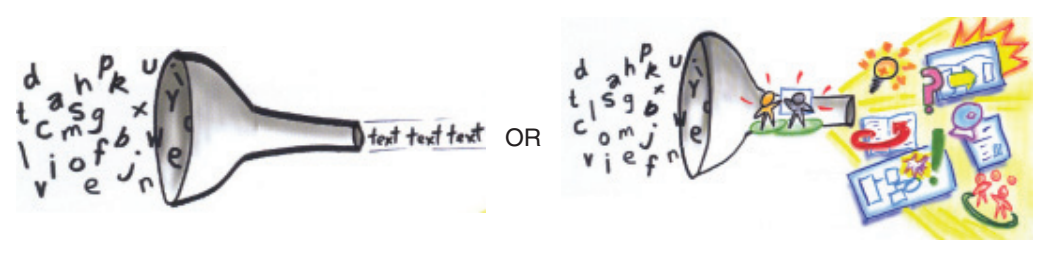

Figure 1: The graphic facilitation process

and Latin (facilis) meaning easy to do, doable. Although the role of the facilitator is to achieve outcomes, it also involves designing and implementing a process that flows to enable an individual or group to reach a meaningful and successful outcome. Facilitation is therefore about process, about focussing on how something is achieved. As the term suggests, graphic facilitation (Sibbett, 1977) has two main components: facilitation and the use of graphics. Graphic facilitation can be regarded as a type of visual note taking - it is used as a way of presenting material, or capturing the ideas, content and feelings of an individual or group. Valenza and Adkins (2009) explain: "it's representing ideas as icons and placing them in context with other ideas. It also uses words, phrases, titles, topics, quotes and buzzwords as graphic symbols on the same field" (p. 38).

The graphic facilitator presents or captures content visually on a large chart in full view of everyone participating. Each chart can be customised to the individual or group and to the nature of the discussion and the goals of the process. The chart provides a platform on which the visual dialogue develops, enabling specific details to be recorded simultaneously presenting the big picture. Kim and Mauborgne (2002) believe that building the process around a visual chart creates much better results than using the traditional written format. The graphic facilitator must be fully present, practise deep and ongoing listening (Sanderson, 2000) and position and integrate the given information on the chart to form a coherent story. A skilled graphic facilitator interprets, bridges, records and connects information bringing "the tools of cognitive understanding to the process, so that the 
moving form of the graphic actively nurtures clearer statements and fresh directions from the meeting members" (Valenza \& Adkins, 2009 , p. 42). In this way, the chart provides a vehicle for thinking together and capturing and linking multiple perspectives, while intrinsically involving the individual or group in shaping and seeing the resulting chart and outcome. The chart immediately captures and reframes information that can be understood at a glance, making it possible for participants to clarify their thoughts (Sibbett, 1977, 2010). The completed chart can be photographed and emailed and/or photocopied and presented to participants so there is no delay for the outcomes of a discussion to be circulated. In this way, the chart can be used as an immediate reminder, or a sharing point with those people unable to be present.

An important part of the graphic facilitator's role is, at appropriate times, to feedback to participants the information on the chart in a sensitive and logical way. Although this honours and validates the participants, it also provides opportunities for reflection and clarification and expansion on content.

\section{Reported outcomes of graphic facilitation}

Tierney (2003) claims that people retain 10\% of information read, $20 \%$ of information heard and $50 \%$ of information seen and heard. Weibord (cited in Tyler, Valek, \& Rowland, 2005) states "people will support what they help to create" (p. 148). Graphic facilitation can provide a compelling platform for people to become engaged when they see their words, expressions and stories visually represented on the chart.

In striving for authenticity and genuineness, understanding of self can be enhanced through using the graphic as a means for clarification and reflection (Congleton, 2011; Horan, 2000).

Ownership of the dialogue is enhanced through the participants' identification with the graphics as they are recorded (Sibbett, 1977; Tyler et al., 2005). Graphic facilitation aligns with a strengths-based practice framework (Gilgun, 2005; Saleebey, 1996) that emphasises power with rather than power over (McCashen, 2005). Amering and Schmolke (2009) state, "freedom of choice is ...being able to bring your own ideas to the table and having the chance to implement them" (p. 63).

It is well documented that people have different processing and learning styles (Armstrong, 1987; Gardner, 1985).

To generate engagement and ownership, it is important to harness the full range of learning styles rather than focussing primarily on the traditional verbal-linguistic ones. The visual is reported to stimulate the mind, the heart and the soul (Bell \& Morse, 2012; Hooper, Low, \& Kearins, 2003). Joffe (2008) discusses the power of visuals as being a "thought to send people along emotive pathways where textual/verbal material leads them in a more rational, logical and linear pathway of thought" (p. 84). Appealing to a wider range of learning styles can create a space where the often-unheard voice can be expressed (Espiner \& Guild, 2008; Tyler et al., 2005). Some participants are silent, reticent to speak out or may feel that they have not had a real opportunity to speak or be heard. This can reinforce feelings of marginalisation and create withdrawal from the group or process. Through appealing to the visual senses, graphic facilitation can go some way to addressing this "dilemma of voice" (Bunker \& Alban, 1997).

Culture gaps can be reduced when participants' own words are recorded and cultural symbols used, to honour and represent cultural identity (Tyler et al., 2005). Accessing information in a written form or as a text narrative can be difficult for some people as standard print may not be accessible or meaningful (Jones \& Shoemaker, 1994). Graphic facilitation can encourage collaborative and mutually respectful ways of talking and working 
together while acknowledging cultural differences.

Tyler et al. (2005) report that levels of interpersonal energy rose when graphic facilitation was employed as the use of colour, form and symbols brought the dialogue alive. The chart is recorded in real time, as the conversation is happening, generating energy, as Joffe asserted, making the experience "especially memorable and the salience that this confers may make it particularly forceful" (2008, p. 85). Graphics can inspire creativity and selfefficacy toward creating solutions among participants as complex ideas are more effectively conveyed through visual image than text (Mullen \& Thompson, 2013; Steenkamp \& Hooks, 2011).

Although graphic facilitation gives rise to ideas, the visual image formed may assist retention as visual images are easier to remember than words or numbers (Armstrong \& Dorsett, 2015; Graber, 1989). The graphics on the chart can be a productive way of organising and summarising ideas and thoughts (Agerbeck, 2012; Kelly, 2005; Roam, 2009; Sibbett, 2008) enabling reflection on the conversation in parts and as it develops as a whole (Tyler et al., 2005).

Graphic facilitation incorporates many of the elements of sense-making (Weick, 1995). These elements are summarised in the quote attributed to E. M. Forster: "How can I know what I think until I see what I say?" When seeking explanations and answers sensemaking challenges people to look outside of traditional systems and structures and to look instead at peoples' way of thinking.

\section{Person-centred planning and graphic facilitation: Potential relevance for social work practice}

Most, if not all, social workers will be involved in planning with clients. Effective planning is person or client-centered, reflecting the unique circumstances and aspirations of the individual person (Williams, Porter, \& Marriott, 2014). A client-centered approach evolved from the work of Carl Rogers (1951) who proposed unconditional positive regard towards clients, empathy toward their situations and genuine interactions (Chenoweth \& McAuliffe, 2015). This humanistic approach is aligned with existentialism focussing on the "capacity of people to gain the personal power to control their lives and change ideas governing their lives" (Payne, 2014, p. 275).

Person-centred planning involves a new way of thinking (Gambrill, 2013) which puts the person's interests and wishes at the centre of the process. It involves listening deeply to the person, their family and friends, and taking the time to discover the person's aspirations (Amando \& McBride, 2001). Action is then taken to support the person meet their aspirations.

Along with a shift in thinking, personcentered planning requires a shift in power dynamics and is embedded in the principles of shared power and self-determination (Sanderson, 2000). This demands a shift in the balance of power removing the professional from imposing their view of the world on the client. Dominelli (1993, cited in Dominelli, 2002) advocates for anti-oppressive practice, which "embodies a person-centred philosophy, an egalitarian value system concerned with reducing the deleterious effects of structural inequalities upon people's lives" (p.24). Anti-oppressive social work requires the social worker to "relinquish pre-set beliefs and professional training in order to listen effectively to how their service users describe their own issues" (Sakamoto \& Pitner, 2005, p. 448). Antioppressive practice is "innovative, evolving and contentious" (Hick, 2002, para. 2) requiring creativity and disentanglement from more traditional ways of practice. Implementing person-centred planning challenges social workers and social service organisations to work in more innovative, responsive and empowering ways. 
Empowerment-orientated practice requires social workers to put aside their expert role and adopt collaborative processes (DuBois \& Miley, 2011) to engage with the lived experience of their clients. Empowerment theory regards people as capable and competent to set goals and design a way of achieving them if given the relevant opportunities and resources (Breton, 1994). Graphic facilitation is a skill that can support shared understanding and collaborative decision-making leading to more creative solutions and pathways.

There are many ways in which graphic facilitation can be used within personcentred planning. This can be through the use of pre-designed (Sanderson Associates, n.d.) or individually tailored templates. Planning Alternate Tomorrow's with Hope (PATH) (Pearpoint, O’Brien, \& Forest, $1995)$ is an example of a visual planning process. A study by Armstrong and Dorsett (2015) claimed that PATH graphics and visuals "resonated" with people living with emotional distress as "the PATH plan stays with the person as a visual compass" (p.42) and "thoughts being visually presented highlighted a potential strength of the relationship between PATH and recovery" (p. 42). The use of images was seen to raise issues and bring ideas "to the surface, visible and conscious" (p. 42). The use of graphics was also found to help people who experience long- or short-term memory loss. One participant in this study of the PATH planning process said, "struggling with long-term concentration [the visual nature of PATH] allows visual achievement" (p. 42).

A study by the authors (Espiner \& Hartnett, 2012) reviewed outcomes from an organisation's efforts to implement a more person-centred approach to personal planning for adults with an intellectual disability. A key outcome of the study was that personal plans with more hand-drawn images, colour and words presented in a creative way were more accessible to the adults. Participants were able to review the plan independently or with support.
The visual content enabled the adults to take greater ownership of their role in implementing their plan as they could read and remember the content, thus being more motivated to follow up and action their plan.

The visual format had enabled the adult to work collaboratively with a staff member and this had created a real sense of ownership. One adult commented, "[Name] and I made the plan. I do not read but I have a book about my plan...I like the pictures 'cos I do not read. I like the colours and the big pictures". Another adult stated "I like the pictures...I bring it out every night".

Staff and family and friends of the adults agreed that the individualised pictorial formats had enabled the adults to remember and understand their goals thus providing motivation through "the confidence and pleasure from being listened to and from holding and 'reading' a document of their own". Another family member believed that the graphic facilitation approach had enabled the adult to express and uncover aspirations of which there was no previous knowledge. One staff member asserted "the facilitation of the meeting helped everyone to help each other to share ideas and to help make [the adult's] dreams come true".

The majority of adults for whom plans were facilitated stated that the planning had created a forum where they had they felt listened to and where their voice had been acknowledged. Graphic facilitation played a major role as expressed by one adult who stated, "People listened to me...they asked me and listened and I felt listened to".

A study by Espiner and Guild (2012) incorporated the use of graphic facilitation into student-centred planning used by a New Zealand school that supported students between the ages of 5 and 21 years who had very high levels of support needs. The use of visuals and graphic recording was seen to be an effective method of facilitating and recording the plan. For an example of a "graphed" individual plan, see Figure 2. 
The student's caregiver who participated in the planning reported:

Having someone doing the graphics and presenting [feeding back] made it a lot more interesting ...The drawing fascinated [Name of student]. It is more visual for her than talking ...it was colourful and bright. She just loved it ...You have to have the visuals for her.

Another participant reported that the visuals were "the way to go". The study indicated greater ownership of the plan as the student pinned her plan on the classroom wall immediately after the planning meeting, and related the "story" of her meeting and the goals to her classmates. After school, she took the plan home and asked her caregiver to mount it on the wall of the dining room; this in itself was an accomplishment. Her caregiver revealed:

In the home [Name of student] destroys things and that is an ongoing problem ... Normally things would get ripped off the wall and shredded, ...but with the plan she hasn't. We've got it up on the wall of dining area and [Name of student] was always talking about it.

The student's teacher remarked, "When I go to her home it is there and I can look at it and see where she is up to ... if it is just typed on paper it is just not the same". One teacher noted that the process enabled participants to "see what were the essential or important goals and what [student] can do, and what we need to do to help". One of the main advantages of the use of visuals was increased engagement for the students and other participants. Seeing the ideas recorded in an accessible and visual way reminded the students of their role as the central participant.

Graphics were also incorporated into the transition planning for students at the same school (Espiner \& Guild, 2011). In one example, a transition planning process was undertaken for a 19-year-old young man

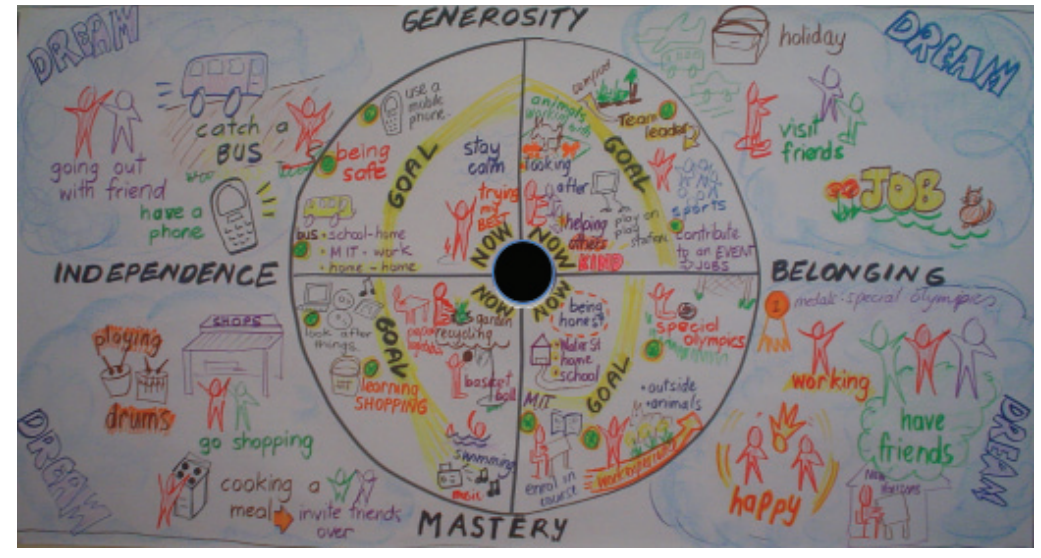

Figure 2: Graphed individual plan

who had not previously been included in his planning even though personal planning had been a feature of his life since he was two years old.

His teacher commented, "If we talk the words, you hear them and they are gone. For students, the pictures are up there for them to look back to - it is part of being visual - it is permanent". The teacher also commented on the importance of reflecting back information, "after each small section was discussed the grapher would feedback this recapture ensured the words and ideas were all recorded and refreshed everybody about where they were".

The young man demonstrated a high level of engagement throughout the planning through his body language and by listening and looking at people when they were talking. His teacher stated that he was "looking, smiling, listening and responding by tapping his mother's hand, his expression of "yes" and "no", and staying for the entire time of the planning".

His mother stated that through "seeing" his plan evolve:

He [Name] was able to figure out what we were actually talking about ...oneand-a-half hours is a long time, [Name] stayed the whole time ...this is a young 
man you could not usually get in the door - but he wanted to come in. When he went out to the toilet I asked him, "Do you want to go back in?" and he went straight in.

Everyone who was part of this planning process agreed that it had created ownership. His mother stated:

If you just had an IEP chart on the wall[Name] has never gone over and checked it out, even though I talked about it, it was only just written words. In this plan you drew pictures, ...his bike, ...his house with him inside it, ...he comes over and looks at it, he checks out his chart. He is doing these tasks-before he would have walked off. He is coming up to the sink and handing me a glass and hand over hand we are putting them in the dishwasher-before he would not do this.

Graphic facilitation aligns with many of the theories that underpin social work practice. As a process it has the potential to promote anti-oppressive practice and selfempowerment, paradigms that are relevant to social workers and the varied contexts in which they work. Graphic facilitation can also offer social workers the opportunity to reflect on their role in more sensitive and relevant ways.

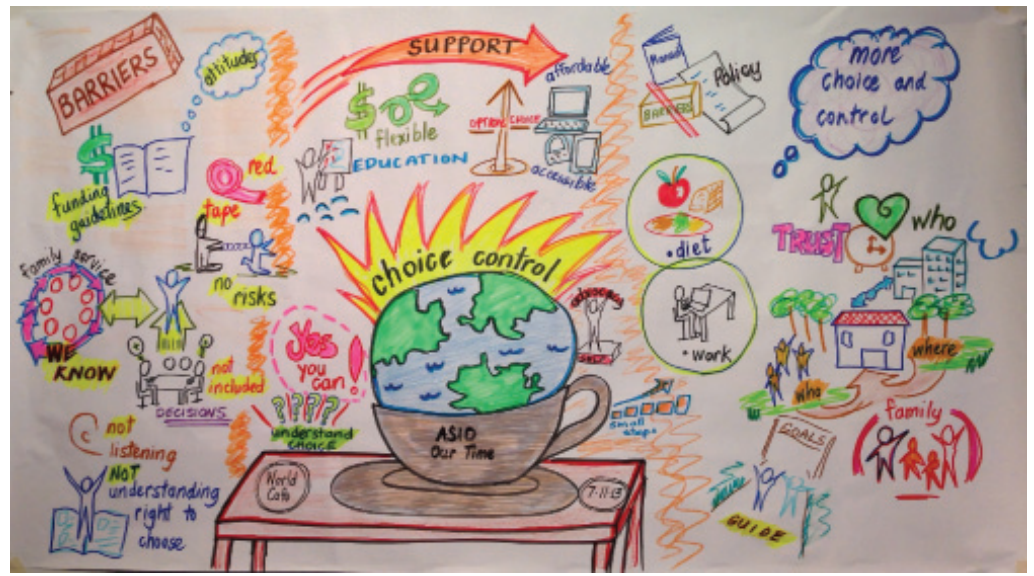

Figure 3: World Café

\section{Creative conversations and graphic facilitation: Potential relevance for social work practice}

Social workers are often faced with complex and at times wicked problems (Roberts, 2000) for which linear thinking and approaches are deemed inadequate. Such problems demand approaches that incorporate multiple perspectives, high degrees of involvement, commitment and coordination. These types of problems necessitate strategies that involve thinking differently, unconventionally or from a new perspectives (Gambrill, 2013; Hafford-Letchfield, Lambley, Spolander, \& Cocker, 2014). Furthermore, strategies for approaching such problems require a collaborative approach and anti-oppressive practices that promote power sharing (McKitterick, 2015), as thinking needs to go beyond the capacity of any one person or group's understanding. Graphic facilitation, through the design and development of highly visual maps, provides a valuable information management tool that can facilitate and navigate problems from new perspectives (Checkland, 1981; Horn, 1998). The visual structure of the dialogue is observable to everyone as the discussion unfolds. The graphic thus has the ability to illustrate emerging arguments, viewpoints and options, structuring the flow of complex discussions to enable a deeper and more rapid analysis of the situation.

One example of deeper and rapid analysis is the World Café approach (Brown \& Isaacs, 2005). The approach is a process that challenges the notion that knowledge is held and shaped by professionals who are the experts. World Café invites participation from non-experts. According to Fouché and Light (2011), World Café embodies "social work values, knowledge generation and information exchange through 'conversations that matter'" (p. 29).

Graphic facilitation has been used successfully at a conference with a large group of participants adopting a World 
Café (Brown \& Isaacs, 2005) approach. The participants formed small groups to discuss a set of questions around a topic of mutual interest. Within each café group individual thoughts were shared, collective knowledge and insights surfaced, in order to gain a deeper understanding of the issue. Each café group shared their insights with the large group and the graphic facilitator made a visual representation (Figure 3) creating a group synthesis and memory.

\section{Conclusion}

Graphic facilitation is a process that aligns with social work values and principles. It is an inclusive process that promotes shared understandings, reflection and collaborative decision-making. It is an innovative and creative process that has the potential to develop the thinking required to respond to ever-changing social contexts (Mauzey \& Harriman, 2003). Graphic facilitation can support people (individually and collectively) to better connect through anticipating change, visualising the process and determining action.

\section{References}

Agerbeck, B. (2012). The graphic facilitator's guide. Chicago, IL: Loosetooth.com Library.

Amando, A. N., \& McBride, M. (2001). Increasing personcentered thinking: Improving the quality of personcentered planning: A manual for person-centered planning facilitators. Minneapolis, MN: University of Minnesota, Institute on Community Integration.

Amering, M., \& Schmolke, M. (2009). Recovery in mental health: Reshaping scientific and clinical responsibilities. Chichester, United Kingdom: Wiley-Blackwell.

Anderson, C. J., \& Imperia, G. (1992). The corporate annual report: A photo analysis of male and female portrayals. International Journal of Business Communications, 29(2), 113-128.

Armstrong, T. (1987). In their own way. New York, NY: Tarcher Press.

Armstrong, M., \& Dorsett, P. (2015). Panning for gold: The personal journey of mental health wellness and its relationship with Planning Alternatives Tomorrows with Hope (PATH). Journal of Social Inclusion, 6(2), 36-50.

Bell, S., \& Morse, S. (2012). How people use rich pictures. In Open University Colloquium. Pictures to help people think and act, 07 March 2012, Open University, Milton Keynes. Blakeney, B., Carleton, P., McCarthy, C., \& Coakley, E. (2009). Unlocking the power of innovation. OJIN: The Online Journal of Issues in Nursing, 14(2), Manuscript 1.
Bracht, N., Kingsbury, L., \& Rissel, C. (1999). A five-stage community organisational model for health promotion. In N. Bracht (Ed.), Health promotion at the community level-2-new advances (pp. 83-104). Thousand Oaks, CA: Sage.

Breton, M. (1994). On the meaning of empowerment and empowerment-oriented social work practice. Social Work With Groups, 17(3), 23-37. doi:10.1300/J009v17n03_03

Brown, J., \& Isaacs, D. (2005). The World Cafe: Shaping our futures through conversations that matter. San Francisco, CA: Berrett-Koelher.

Brown, L. (2010). Balancing risk and innovation to improve social work practice. British Journal of Social Work, 40(4), 1211-1228

Bunker, B., \& Alban, B. (1997). Large group interventions: Engaging the whole system for rapid change. San Francisco, CA: Jossey-Bass.

Checkland, P. (1981). Systems thinking, systems practice. Chichester, England: John Wiley \& Sons.

Chenoweth, L., \& McAuliffe, D. (2015). The road to social work and human service practice: An introductory text, 4th ed. Southbank, VIC, Australia: Thomson.

Coholic, D. A., \& Eys, M. (2016). Benefits of an arts-based mindfulness group intervention for vulnerable children. Child and Adolescent Social Work Journal, 33(1), 1-13. doi:10.1007/s10560-015-0431-3

Congleton, C. (2011). Action research at LILA: Exploring the role of graphic facilitation in adult learning. Retrieved from http://www.think-incolour.com.au/wpcontent/ uploads/2012/05/Congleton_AR-final_5-11.pdf

Dominelli, L. (2002). Anti-oppressive practice in context. In R. Adams, L. Dominelli, \& M. Payne (Eds.), Social work: Themes, issues and critical debates, 2nd ed. (pp. 3-19). New York, NY: Palgrave.

DuBois, B., \& Miley, K. (2011). Social work: An empowering profession, 7th ed. Upper Saddle River, NJ: Prentice Hall.

Espiner, D. A., \& Guild, D. (2008). Turning up the volume: Young adults reflect on their secondary school experience. In C. Rubie-Davies \& C. Rawlinson (Eds.), Challenging thinking about teaching and learning (pp. 244-271). Hauppauge, NY: Nova Science Publishers.

Espiner, D. A., \& Guild, D. (2011). The circle of courage in transition planning. Reclaiming Children and Youth, 20(2), 44-49. Retrieved from http://hdl.handle. net/2292/11301

Espiner, D., \& Hartnett, F. M. (2012). "I felt I was in control of the meeting": Facilitating planning with adults with an intellectual disability. British Journal of Learning Disabilities, 4O(1), 62-70. doi:10.1111/j.14683156.2011.00684.x

Espiner, D. A., \& Guild, D. (2012). Capturing what matters most: Engaging students and their families in educational planning. Teaching Exceptional Children, 44(5), 56-67.

Fouché, C., \& Light, G. (2011). An invitation to dialogue: The World Café in social work. Qualitative Social Work, 10(1), 28-48. doi:10.1177/1473325010376016

Gambrill, E. (2013). Social work practice: A critical thinker's guide, 3rd ed. New York, NY: Oxford University Press.

Gardner, H. (1985). Frames of mind: Theory of multiple intelligences. New York, NY: Basic Books. 
Gilgun, J. F. (2005). The 4-D: Strengths-based assessment instruments for youth their families and communities. Journal of Human Behaviour in the Social Environment, 10(4), 454-473.

Graber, D. A. (1989). Content and meaning: What's it all about? The American Behavioral Scientist, 33(2), 144-152.

Hafford-Letchfield, T., Lambley, S., Spolander, G., \& Cocker, C. (2014). Inclusive leadership in social work and social care. Bristol, United Kingdom: Policy Press.

Hick, S. (2002). Introduction to anti-oppressive practice: Challenges for social work. Critical Social Work, 3, 1. Retrieved from http://www1.uwindsor.ca/ criticalsocialwork/2002-volume-3-no-1

Ho, R. T. H., Potash, J. S., Ho, A. H. Y., Ho, V. F. L., \& Chen, E. Y. H. (2016). Reducing mental illness stigma and fostering empathic citizenship: Community arts collaborative approach. Social Work in Mental Health. doi:10.1080/15332985.2016.1236767

Hooper, K., Low, J., \& Kearins, H. (2003). Pictures in New Zealand annual reports: Winner \& losers. Asia Pacific Public Relations Journal, 3(2), 83-107.

Horan, P. (2000). Using rich pictures in information systems teaching. Proceedings of the First International Conference on Systems Thinking in Management (pp. 257-262). Geelong, Australia.

Horn, R. E. (1998). Visual language: Global communication for the $21^{\text {st }}$ century. Bainbridge Island: MacroVU Press. Retrieved from http://www.stanford.edu/ rhorn/ SpchPackard.html

Joffe, H. (2008). The power of visual material: Persuasion, emotion and identification. Diogenes, 55(1), 84-93. doi:10.1177/039219210708791

Jones, M. J., \& Shoemaker, P. A. (1994). Accounting narratives: A review of empirical studies of content and readability. Journal of Accounting Literature, 13, 142-184.

Känkänen, P., \& Bardy, M. (2014). Life stories and arts in child welfare: Enriching communication. Nordic Social Work Research, 4(1), 37-51. doi:10.1080/215685 $7 \times .2013 .781536$

Kelly, S. (2005). The benefits of using graphic recording/graphic facilitation. Retrieved from http://www.theworldcafe.com/pdfs/graphicBenefits.pdf

Kim, W. C., \& Mauborgne, R. (2002). Charting your company's future. Harvard Business Review, 7-83.

Mauzey, J., \& Harriman, R. (2003). Creativity inc: Building an inventive organization. Boston, MA: Harvard Business School Press.

McCashen, W. (2005). The strengths approach. Bendigo, VIC, Australia: St. Luke's Innovative Resources.

McKitterick, B. (2015). Self-leadership in social work: Reflections from practice. Chicago, IL: Policy Press.

Mendoza Straffon, L. (2014). Art in the making: The evolutionary origins of visual art as a communication signal. Department of Art History, Leiden University Centre for the Arts in Society (LUCAS), Faculty of Humanities, Leiden University, Leiden, Netherlands.

Merkley, C. (2005). The history and evolution of the graphic facilitation/recording field. Retrieved from http://www.makemark.com/articles/

Mullen, K., \& Thompson, J. (2013). Graphic recording: Using vivid visuals to communicate climate change.
The Electronic Journal of Communication, 23.

Retrieved from http://www.cios.org/www.cios.org/ EJCPUBLIC/023/3/023034.html

Nandan, M., London, M., \& Bent-Goodley, T. (2015). Social workers as social change agents: Social innovation, social intrapreneurship, and social entrepreneurship. Human Service Organizations: Management, Leadership and Governance, 39(1), 38-56. doi:10.1080/23303131. 2014.955236

Payne, M. (2014). Modern social work theory, 4th ed. Houndsmills, United Kingdom: Palgrave Macmillian.

Pearpoint, J., O’Brien, J., \& Forest, M. (1995). PATH: A workbook for planning positive possible futures. Toronto, ONT: Inclusion Press.

Roam, D. (2009). Unfolding the napkin: The hands-on method for solving complex problems with simple pictures. London, England: Portfolio.

Roberts, N. (2000). Wicked problems and network approaches to resolution. International Public Management Review, 1(1). Retrieved from http://www.ipmr.net CInternational Public Management Network.

Rogers, C. (1951). Client-centred therapy: Its current practice, implications and theory. London, United Kingdom: Constable.

Roose, R., Roets, G., Van Houte, S., Vandenhole, W., \& Reynaert, D. (2013). From parental engagement to the engagement of social work services: Discussing reductionist and democratic forms of partnership with families. Child and Family Social Work, 18, 449-457 doi:10.1111/j.1365-2206.2012.00864

Sakamoto, I., \& Pitner, R. (2005). Use of critical consciousness in anti-oppressive social work practice: Disentangling power dynamics at personal and structural levels. British Journal of Social Work, 35, 435-452. doi:10.1093/bjsw/bch190Saleebey, D. (1996). The strengths perspective in social work practice: Extensions and cautions. Social Work, 41(3), 296-305. doi:10.1093/ sw/41.3.296

Sanderson, H. (2000). Person-centred planning: Key features and approaches. York: Joseph Rowntree Foundation.

Sanderson Associates (n.d.). Person-centred thinking tools. Retrieved from http://www.helensandersonassociates. co.uk/person-centred-practice/person-centred-thinkingtools/

Sibbett, D. (1977). "I see what you mean!" A guide to group graphics. San Francisco, CA: Author.

Sibbett, D. (2002). The facilitator's handbook: A quick guide to inclusion facilitation. Nottingham, United Kingdom: Inclusion Solutions.

Sibbett, D. (2008). Visual intelligence: Using the deep patterns of visual language to build cognitive skills. Theory into Practice, 47(2), 118-127. doi:10.1080/ 00405840801992306

Sibbett, D. (2010). Visual meetings: How graphics, stick notes and idea mapping can transform group productivity. Hoboken, NJ: John Wiley \& Sons

Simpson, L. (2000). The annual report: An exercise in ignorance? Accounting Forum, 24(3), 231-247.

Steenkamp, N., \& Hooks, J. (2011). Does including pictorial disclosure of intellectual capital resources make a difference? Pacific Accounting Review, 23(1), 52-58. 
Tierney, P. R. (2003). The competitive advantages of rich media. Special Supplement to E Content and Information Today, June, S4-S5. Retrieved from http://www.econtentmag.com/ Downloads/Whitepapers/jun03/tierney.pdf

Tyler, C., Valek, L., \& Rowland, R. (2005).Graphic facilitation and large-scale interventions supporting dialogue between cultures at a global, multicultural, interfaith event. The Journal of Applied Behavioral Science, 41(1), 139-152. doi:10.1177/0021886304272850

Valenza, C., \& Adkins, J. (2009). Understanding visual thinking: The history and future of graphic facilitation. Interactions, 16(4), 38-43. doi:10.1145/1551986.1551994

Weick, K. E. (1995). Sense-making in organisations. Thousand Oaks, CA: Sage.

Williams, V., Porter, S., \& Marriott, A. (2014). Your life, your choice: Support planning led by disabled people's organisations. British Journal of Social Work, 44(5), 1197-1215. 